\title{
Optimization of beach profile spacing: an applicable tool for coastal monitoring
}

\author{
JUAN JOSÉ MUÑOZ-PEREZ ${ }^{1}$, ANDRÉS PAYO ${ }^{2}$, JORGE ROMAN-SIERRA ${ }^{1}$, \\ MARINA NAVARRO ${ }^{1}$ and LUÍS MORENO ${ }^{3}$ \\ ${ }^{1}$ Applied Physics Dept., University of Cadiz, Pol. Rio San Pedro s/n, 11510 Puerto Real, Cadiz, Spain. \\ E-mail: juanjose.munoz@uca.es \\ ${ }^{2}$ Dept. of Civil and Environmental Engineering, Kumamoto University, Kumamoto, 860-8555, Japan \\ ${ }^{3}$ Coastal Engineering Division, Intecsa-Inarsa S.A., Santa Leonor 32, 28037 Madrid, Spain.
}

\begin{abstract}
SUMMARY: This paper presents a simplified and straightforward method for determining optimal beach profile spacing from an economic point of view with an admissible error. This error can be computed theoretically by comparing different profile spacings from two consecutive bathymetries. When a beach sediment budget (from previous monitoring surveys) or the volume density of a beach nourishment project is known, a virtual bathymetry can be designed; therefore, a unique real bathymetry would be needed. The method is applied and analysed for beaches with different characteristics regarding tide, energy, morphology and natural features. The results indicate that the estimated errors are proportional to a beach heterogeneity factor, depending on each particular beach case, such that large spacings do not necessarily induce large errors. In our case, profile spacings of $100 \mathrm{~m}$ induce average errors of less than $5 \%$. Moreover, differences in tidal range and the existence of rocky reefs do not seem to affect the results.
\end{abstract}

Keywords: beach monitoring, beach profile spacing, volume error, erosion rate, beach nourishment, topographic surveying.

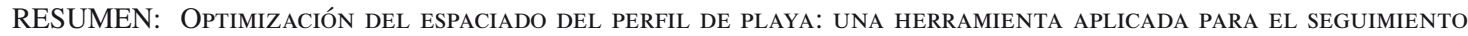
COSTERO. - Se presenta una metodología sencilla para, una vez admitido un cierto error relativo, determinar la separación máxima (i.e. un coste mínimo) entre los perfiles del seguimiento de una playa. El error puede calcularse teóricamente mediante la comparación de datos de diferentes separaciones obtenidos de dos batimetrías consecutivas. En algunos casos, cuando se realiza un proyecto de realimentación o se conoce el balance de arena de una playa (debido a seguimientos previos), puede diseñarse una batimetría virtual, bastando entonces con una única batimetría real. El método se analiza para diferentes tipos de playa dependiendo de su naturaleza morfológica, mareal y energética, así como otras características. Los resultados indican que el error estimado es también proporcional a un factor de heterogeneidad característico de cada playa, de tal manera que grandes separaciones no conllevan necesariamente grandes errores. En nuestro caso, separaciones de 100 $\mathrm{m}$ inducen errores inferiores al 5\%. Además, en cuanto a la carrera de marea y a la existencia de lajas rocosas, los resultados no parecen mostrar diferencias.

Palabras clave: seguimiento de playas, espaciado del perfil de playa, error volumétrico, tasa de erosión, realimentación de playas, estudios topográficos.

\section{INTRODUCTION}

\section{Beach survey designing}

Understanding the dynamic behaviour of a beach is essential for effective engineering design and requires short- and long-term monitoring, which includes periodic and emergency topo-bathymetric surveys (Jimen- ez and Sanchez-Arcilla 1993) based on profiling or on grid surveys. It is true that grid surveys provide accurate assessments of three-dimensional (3D) coastal morphology, but they also require a high density of topographic and bathymetric data points to generate 3D surface maps (Bernstein et al. 2003). Some authors (e.g. Swales 2002) state that although repetitive shore-normal profiles accurately describe morphology 
changes at discrete locations and are critical for historical change analysis, using traditional $2 \mathrm{D}$ profiles to describe the true 3D morphology assumes little variation in the alongshore direction. However, whether we use 3D mapping or a profiling strategy, the final aim is to apply a simplified and cost-effective method for determining changes in beach volume. Such a method would allow a coastal manager to design a coastal maintenance strategy that takes into account the majority of beach spatial variability.

Several techniques have been developed to measure water depth and shoreline changes (Jimenez et al. 1997). LIDAR (LIght Detection And Ranging), for instance, can provide an inexpensive and accurate baseline for morphosedimentary analyses (Irish and White 1998, Moreno et al. 2007); the same can be achieved using a video-monitoring station based on the Argus technique (Aarninkhof and Holman 1999, Holman and Stanley 2007, Garnier et al. 2010). However, LIDAR is only useful in large areas because of the significant cost of aircraft use. In addition, multibeam surveying is not recommended for nearshore projects (USACE 2002). Finally, cross-shore surveying using a Coastal Research Amphibious Buggy (CRAB) or sea sled is the best method because of its accuracy. However, there are areas where this solution is impractical (Wise 1995). For instance, in areas with rocky outcrops, submarine canyons or extensive reef flats (Muñoz-Perez et al. 1999), submerged surveys must be carried out by boat with a properly calibrated echo sounder.

Therefore, at least in the medium term, the most common way to perform such surveys is to conduct land and wading surveys using ordinary topographic procedures and to merge these data with offshore surveys using an echo sounder to obtain depth measurements (Dean 2002). Clearly, landward and seaward surveys should be performed at low and high tides, respectively, to maximize the overlap (Grosskopf and Kraus 1993). Various methods and their corresponding accuracies for surveying using an echo sounder have been described by the National Ocean Survey (NOS 1980), IHO (1998) and USACE (2002).

\section{Coastal monitoring applications}

Considerations of strategic coastal management imply relevant key components such as analysis, planning, management and monitoring (Micallef and Williams 2002). Due to the loss of beach sediment supplies caused by continuous erosion problems or natural disasters, beach nourishment has become the coastal management "tool of choice" over the last several decades (Stauble et al. 1993, Browder and Dean 2000, Rogers 2000, Hanson et al. 2002, Menezes and Klein 2006).

According to Wise (1995), monitoring beach nourishment requires a large number of topo-bathymetric surveys (quarterly during the year following nourishment works and biannually for at least one additional post-nourishment year). Because it is not economically feasible to survey an entire area, the number of profiles measured must be decided beforehand. For the same beach, an increase in the number of measured profiles decreases the error associated with discretizing the domain. However, increasing the number of profiles increases, among other things, the survey budget. Thus, a compromise must be found between the error of estimation and the available budget. Some recommendations regarding beach profile spacing can be found in the literature. For example, Grosskopf and Kraus (1993), Wise (1995) and Browder and Dean (2000) suggested a spacing of the order of $300 \mathrm{~m}$ (1000 ft) on long straight beaches such as those in Florida and Maryland, with a reduction of this spacing by half $(150 \mathrm{~m}, 500 \mathrm{ft})$ close to project endpoints, tidal inlets or structures or areas where the shoreline orientation changes sharply (Wright and Short 1984, Lippmann and Holman 1990). The Coastal Engineering Manual (USACE 2002) recommends that beach fill project plans should depict existing conditions and that the construction template at regular intervals along the shoreline should not be greater than $150 \mathrm{~m}$. However, pre- and post-nourishment profile surveys are routinely collected at higher resolutions (spacings of 60 $\mathrm{m}$ or less) to determine placement volumes accurately for payment purposes. This procedure is not used all over the world (Muñoz-Perez et al. 2001a).

It is evident that surveys should have a high level of accuracy. Grosskopf and Kraus (1993) proposed a mean error of less than $11.5 \mathrm{~m}^{3} / \mathrm{m}(5 \mathrm{cu} \mathrm{yd} / \mathrm{ft})$ of beach volume to estimate sand volume with an accuracy comparable to the $10 \%$ to $20 \%$ contingencies associated with project designs.

A few investigations have described errors related to typical beach bathymetric data sets and their influence on quantitative and qualitative interpretations of nearshore processes (e.g. Plant et al. 2002). However, no one has yet studied the error associated with the choice of profile spacing. Therefore, the goal of this study was to determine the most cost-efficient profile spacing related to a specific allowable error.

\section{STUDY AREA}

The method presented herein was verified by calculating the real error for different kinds of beach along the Spanish coast (Victoria Beach in Cadiz, Puzol Beach in Valencia, and Miracle Beach in Tarragona) and the United States Atlantic Coast (Duck Beach in Dare County, North Carolina), the location and photographs of which are shown in Figure 1.

The chosen beaches have different characteristics: Puzol and Miracle Beach are located on the Mediterranean Sea, so their tidal range is negligible, which is also the case for Duck Beach. However, Victoria Beach has a meso-tidal range of almost 4 metres. This beach has another peculiarity: its approximately $3 \mathrm{~km}$ length is divided into two zones, each one of $1500 \mathrm{~m}$. It has a nearly horizontal reef flat at the lowest low water level (LLWL) in the northern part but not in the southern part 

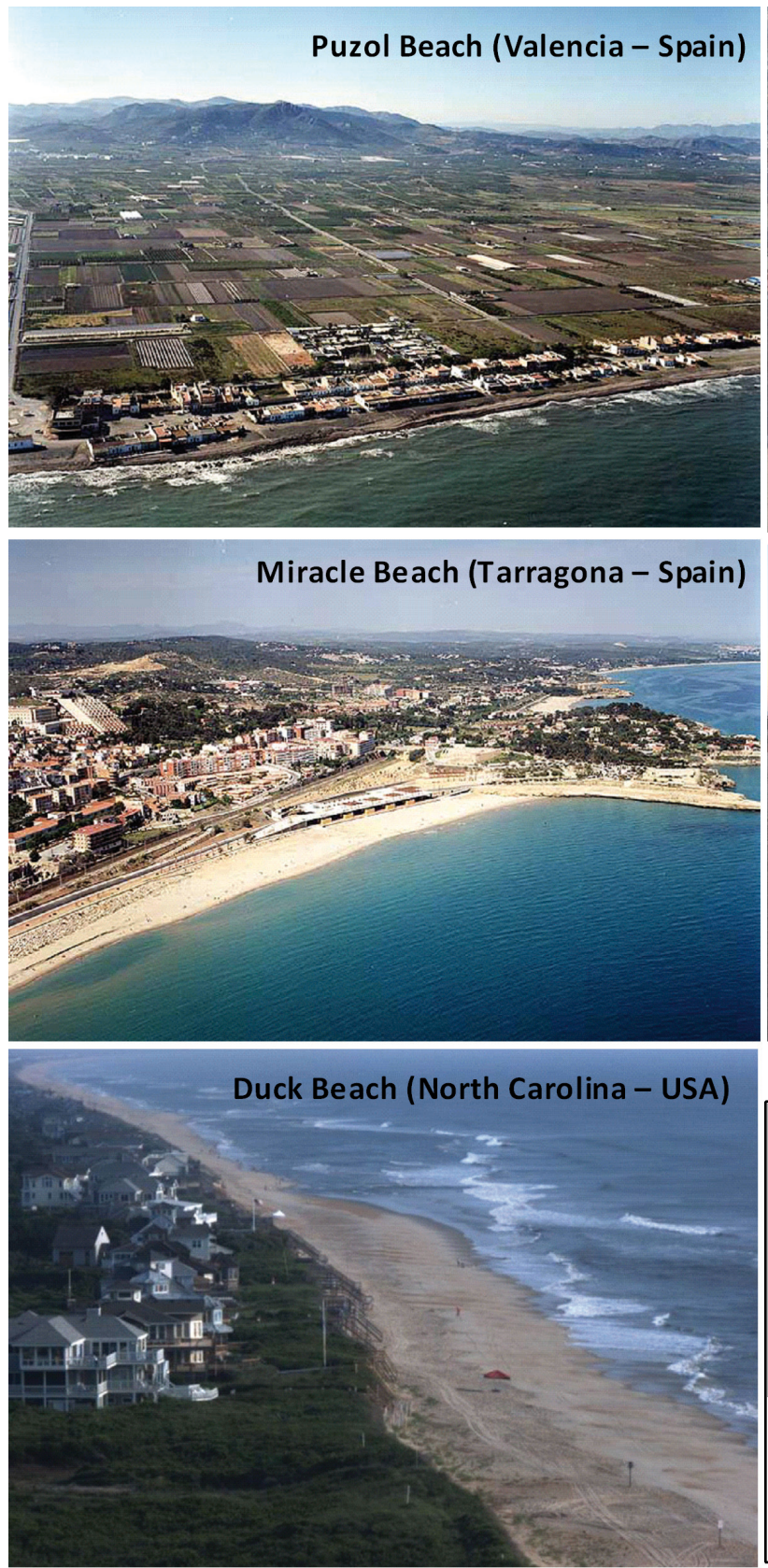

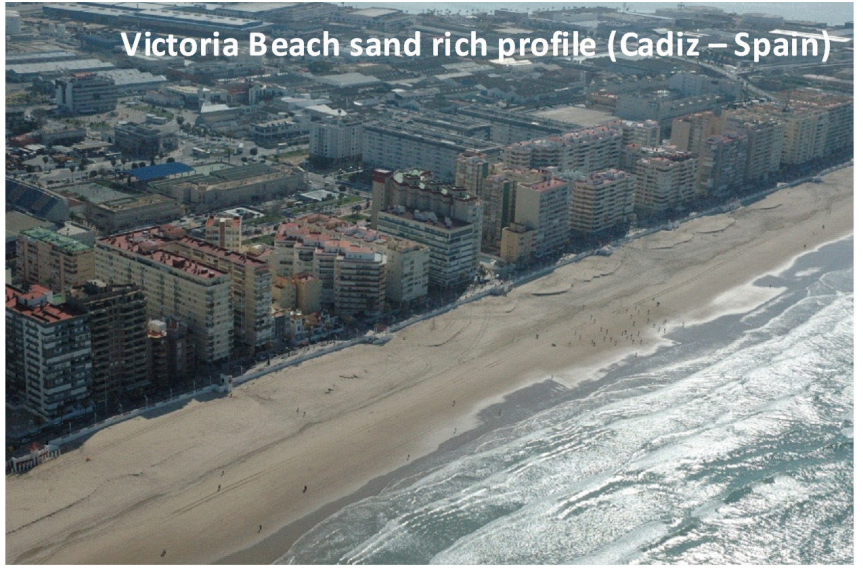

Victoria Beach with reef flat(Cadiz - Spain)

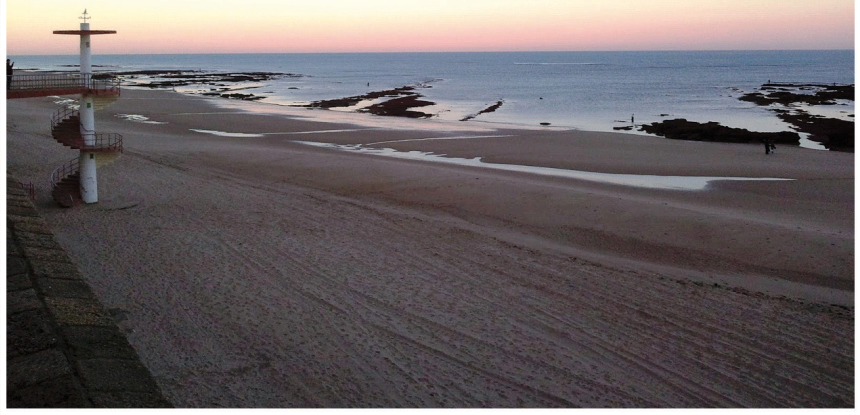

Beach locations:

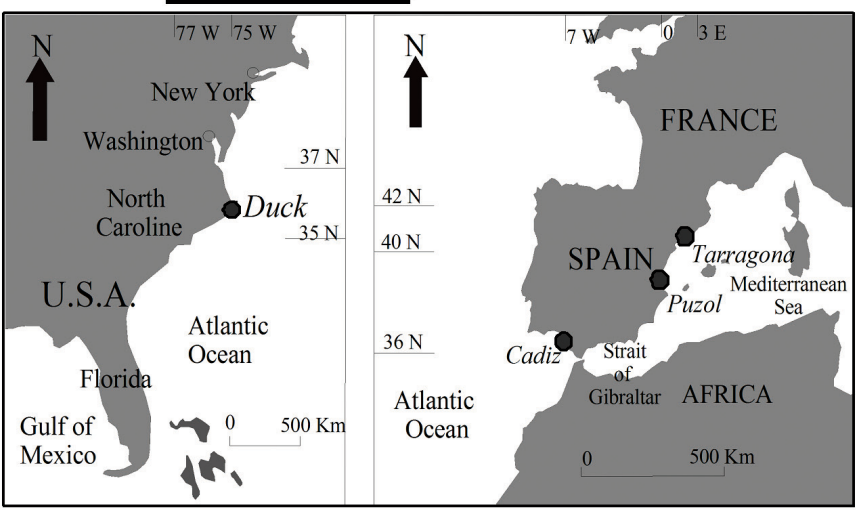

FIG. 1. - Location and photographs of the beaches studied.

TABLE 1. - Parameters related to the studied beaches. $\mathrm{D}_{50}$, sand mean grain size; Average slope, percentage of slope related to the mean profile; TR, tidal range; $\mathrm{H}_{\mathrm{s}}$, significant wave height; $\mathrm{h}_{*}$, closure depth in relation to the lowest low water level.

\begin{tabular}{|c|c|c|c|c|c|c|c|c|}
\hline Beach name and type & $\begin{array}{c}\mathrm{D}_{50} \\
(\mu \mathrm{m})\end{array}$ & $\begin{array}{c}\text { Beach } \\
\text { length }(\mathrm{m})\end{array}$ & $\begin{array}{l}\text { Profile } \\
\text { length }(\mathrm{m})\end{array}$ & $\begin{array}{l}\text { Average } \\
\text { slope (\%) }\end{array}$ & $\begin{array}{l}\mathrm{TR} \\
(\mathrm{m})\end{array}$ & $\begin{array}{l}\mathrm{H}_{\mathrm{s}} \\
(\mathrm{m})\end{array}$ & $\begin{array}{c}\text { Berm } \\
\text { elevation (m) }\end{array}$ & $\begin{array}{l}\mathrm{h}_{*} \\
(\mathrm{~m})\end{array}$ \\
\hline Victoria (Atlantic reef-flat beach) & 250 & 1500 & 600 & 1.9 & 3.8 & 3.7 & 4.80 & -3.2 \\
\hline Victoria (Atlantic sand-rich beach) & 250 & 1500 & 500 & 2.0 & 3.8 & 3.7 & 4.73 & -3.2 \\
\hline Puzol (Mediterranean straight beach) & 200 & 2000 & 150 & 4.7 & 0.7 & 2.9 & 1.90 & -2.1 \\
\hline Miracle (Mediterranean headland-bay beach) & 220 & 1000 & 250 & 3.3 & 0.5 & 2.7 & 1.87 & -3.0 \\
\hline Duck (Atlantic straight beach) & 210 & 1500 & 250 & 5.1 & 1.20 & 1.0 & 3.02 & -6.9 \\
\hline
\end{tabular}

(Muñoz-Perez and Medina 2010). This particular feature is used to compare the results. All of these beaches have a long straight shoreline, with the exception of
Miracle Beach, which has a half-heart shape because it is a headland-bay beach. The mean sand grain sizes of the beaches are very similar and range from $200 \mu \mathrm{m}$ 
at Puzol Beach to $290 \mu \mathrm{m}$ at Victoria Beach. In addition, there is no significant difference between the corresponding $\mathrm{Hs}_{12}$ records (i.e. non-breaking significant wave height only exceeded $12 \mathrm{~h} /$ year). These values, in addition to other parameters such as shore length, tidal range, significant wave height $\left(\mathrm{H}_{\mathrm{s}}\right)$, closure depth $\left(\mathrm{h}_{*}\right)$, and average slope at each beach, are shown in Table 1.

\section{METHODOLOGY}

\section{Initial real bathymetry surveys}

A topo-bathymetric survey was conducted at beaches with different features (e.g. tidal range, wave power, sediment size, beach slope, depth of closure, degree of headland protection and presence or absence of a reef flat).

According to Dean (2002), if the objective of beach surveys is to quantify the volume of sand remaining in a project area, the profiles should extend to depths that exceed the closure depth (i.e. the seaward limit of effective seasonal profile fluctuations, according to Hallermeier 1981). Therefore, cross-shore profiles were acquired at each beach from the berm (dry beach) to 1.2 times the depth of closure. All profiles were taken perpendicular to the coastline (all being parallel to each other except those of Miracle Beach because of its curvilinear shape).

Several procedures have been used to survey both landward and seaward areas that are merged at the land/water interface, the accuracy of the landward procedures being greater than those applied to seaward zones (Muñoz-Perez et al. 2001b). The hydrographical survey on Duck Beach was conducted by a Coastal Research Amphibious Buggy. In the case of the Spanish beaches, topographic and bathymetric measurements were taken with a sounding loaded on a vessel and monitored by a Differential Global Position System (DGPS), such as that applied by Navarro et al. (2011). Each survey campaign lasted at most two days, taking advantage of the spring tides. The hightide hours were exploited to obtain submerged data as close as possible to the shore because of the low draft. On the other hand, topographical measurements were taken during low-tide periods on the same dates. Any decisions about rod stations were left to the rod man because of his extensive training. This approach made it possible to distinguish those locations where pronounced changes in the topography are to be found and reach a depth of $-1.00 \mathrm{~m}$. An extended overlapping area from both data sets collected was covered by using this arrangement.

The profile spacing of the initial bathymetric surveys was always $50 \mathrm{~m}$, with a maximum surveyed length of $1000 \mathrm{~m}$ at every beach. A mean profile for each beach was computed based on the 50-m crossshore profile average. The average profile and standard deviation of the original topography of each beach studied are shown in Figure 2.
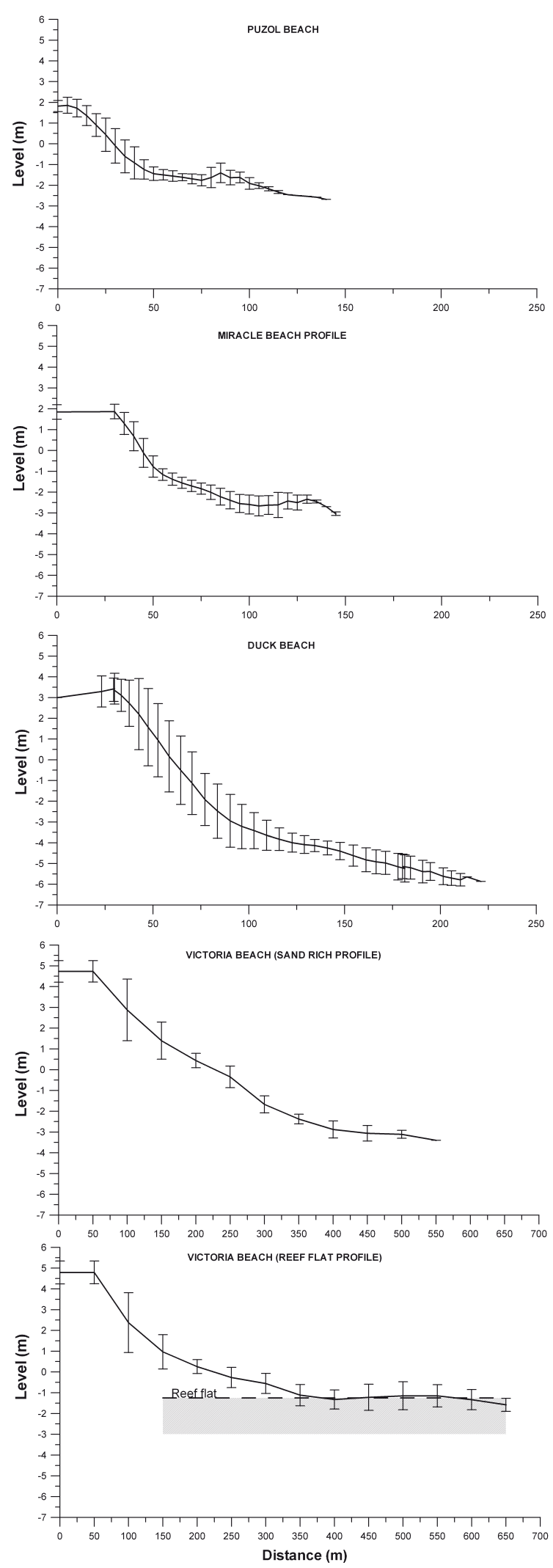

FIG. 2. - Mean profiles of various beaches along the Spanish coast (Victoria Beach in Cadiz, Puzol Beach in Valencia, and Miracle Beach in Tarragona) and the United States Atlantic Coast (Duck Beach in Dare County, North Carolina). 


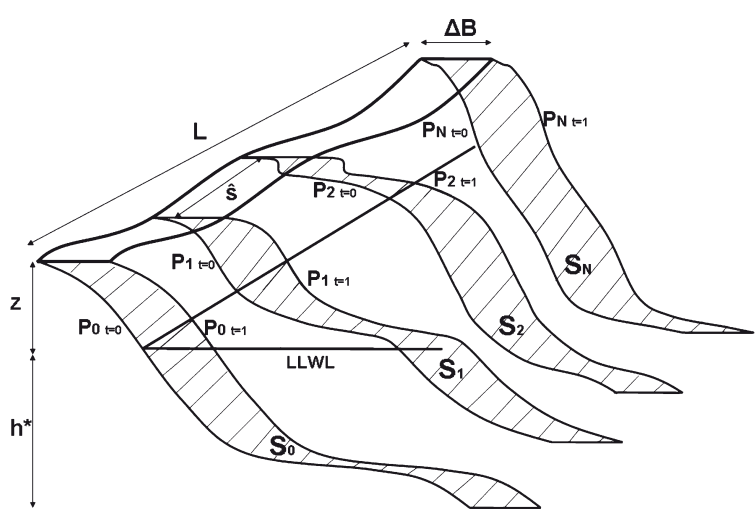

FIG. 3. - Sketch showing $\mathrm{N}+1$ cross-shore profiles $\left(\mathrm{P}_{0}, \mathrm{P}_{1}, \mathrm{P}_{2}, \mathrm{P}_{3}\right.$, $\ldots ., \mathrm{P}_{\mathrm{N}}$ ) with a spacing of $\hat{s}$. Net areas between profiles of different bathymetries are designated $\mathrm{S}_{0}, \mathrm{~S}_{1}, \mathrm{~S}_{2}, \mathrm{~S}_{3}, \ldots, \mathrm{S}_{\mathrm{N}}$. Lowest low water level (LLWL) is the elevation reference or datum. Virtual beach width displacement $(\Delta \mathrm{B})$, berm height $(\mathrm{z})$ and closure depth $\left(\mathrm{h}^{*}\right)$ are also indicated.

\section{Theoretical error computation}

To compute the volume changes, $N+1$ cross-shore profiles with a spacing of $\hat{s}$ are needed $\left(\mathrm{P}_{0}, \mathrm{P}_{1}, \mathrm{P}_{2}, \mathrm{P}_{3}\right.$, ..., $\mathrm{P}_{\mathrm{N}}$ ) (Fig. 3). Obviously, the total length of the beach, $L$, is $\hat{S} \cdot N$. In practice, two bathymetric surveys must be conducted with a short spacing (e.g. $\hat{s}=50 \mathrm{~m}$ ).

A set of areas $\left(S_{0}, S_{1}, S_{2}, S_{3}, \ldots, S_{N}\right)$ is obtained by comparing two sets of real cross-shore profiles corresponding to two different dates ( $\mathrm{t}=0$ and $\mathrm{t}=1)$, as can be seen in Figure 3.

The total volume $\mathrm{V}_{s}$ is obtained as the sum of all prismatoids:

Thus,

$$
\begin{gathered}
\mathrm{V}_{S}=\hat{s} \cdot\left[\left(\mathrm{S}_{0}+\mathrm{S}_{1}\right) / 2+\left(\mathrm{S}_{1}+\mathrm{S}_{2}\right) / 2+\left(\mathrm{S}_{2}+\mathrm{S}_{3}\right) / 2+\right. \\
\left.+\ldots+\left(\mathrm{S}_{\mathrm{N}-1}+\mathrm{S}_{\mathrm{N}}\right) / 2\right] .
\end{gathered}
$$

$$
\mathrm{V}_{S}=\hat{s} \cdot\left[\mathrm{S}_{0} / 2+\mathrm{S}_{1}+\mathrm{S}_{2}+\mathrm{S}_{3}+\ldots+\mathrm{S}_{\mathrm{N}-1}+\mathrm{S}_{\mathrm{N}} / 2\right] .
$$

It is easily noted that

$$
\mathrm{V}_{S}=\mathrm{D} \cdot \mathrm{L}=\mathrm{D} \cdot \hat{s} \cdot \mathrm{N},
$$

where $\mathrm{D}$ is the volume density, i.e. the nourished volume per unit length of beach, which is usually expressed as $\mathrm{m}^{3} / \mathrm{m}$ (Dean 2002) or a factor corresponding to the average erosion rate when the goal is long-term monitoring.

Let us assume that the above computed volume $\left(\mathrm{V}_{S}\right)$ is the most accurate estimate available. Furthermore, cross-shore profiles corresponding to wider spacings, for instance, $2 \hat{s}, 3 \hat{s}, \ldots, \mathrm{n} \hat{s}, \ldots, \mathrm{N} \hat{s}$, can be collected and the associated volumes, $\mathrm{V}_{2 S}, \mathrm{~V}_{3 S}, \ldots, \mathrm{V}_{n \cdot S}, \ldots, \mathrm{V}_{N \cdot S}$, can be computed.

Applying Eqation (2), we obtain

$$
\mathrm{V}_{2 S}=2 \hat{s} \cdot\left[\mathrm{S}_{0} / 2+\mathrm{S}_{2}+\mathrm{S}_{4}+\mathrm{S}_{6}+\mathrm{S}_{8}+\ldots+\mathrm{S}_{\mathrm{N}-2}+\mathrm{S}_{\mathrm{N}} / 2\right],
$$

$$
\begin{gathered}
\mathrm{V}_{3 S}=3 \hat{s} \cdot\left[\mathrm{S}_{0} / 2+\mathrm{S}_{3}+\mathrm{S}_{6}+\mathrm{S}_{9}+\ldots+\mathrm{S}_{\mathrm{N}-3}+\mathrm{S}_{\mathrm{N}} / 2\right], \\
\mathrm{V}_{N S}=\mathrm{N} \cdot \hat{s} \cdot\left[\mathrm{S}_{0} / 2+\mathrm{S}_{\mathrm{N}} / 2\right] .
\end{gathered}
$$

In general,

$\mathrm{V}_{n S}=\mathrm{n} \cdot \hat{s} \cdot\left[\mathrm{S}_{0} / 2+\sum \mathrm{S}_{\mathrm{n}^{*}}+\mathrm{S}_{\mathrm{N}} / 2\right] \quad \mathrm{n}=1, \ldots, \mathrm{N}$,

where the $n^{*}$ are multiples of $n$, and $\sum S_{n^{*}}$ is the sum of the areas of the respective cross-shore profiles.

The relative error of each subset of profiles, $\mathrm{V}_{n S}$, with respect to the most accurate one, $\mathrm{V}_{\mathrm{S}}$, is defined as follows:

$$
\varepsilon=\left(\mathrm{V}_{n S}-\mathrm{V}_{\mathrm{S}}\right) / \mathrm{V}_{\mathrm{S}}
$$

Substituting,

$$
\begin{gathered}
\varepsilon=\left(\mathrm{n} \cdot \hat{s} \cdot\left[\mathrm{S}_{0} / 2+\sum \mathrm{S}_{\mathrm{n}^{*}}+\mathrm{S}_{\mathrm{N}} / 2\right]-\hat{s} \cdot\left[\mathrm{S}_{0} / 2+\mathrm{S}_{1}+\mathrm{S}_{2}+\mathrm{S}_{3}+\ldots\right.\right. \\
\left.\left.\ldots+\mathrm{S}_{\mathrm{N}-1}+\mathrm{S}_{\mathrm{N}} / 2\right]\right) / \mathrm{D} \cdot \mathrm{L}, \\
\varepsilon=\left[(\mathrm{n}-1) \cdot\left(\left(\mathrm{S}_{0}+\mathrm{S}_{\mathrm{N}}\right) / 2+\sum \mathrm{S}_{\mathrm{n}^{*}}\right)-\sum \mathrm{S}_{\neq \mathrm{n}^{*}}\right] \cdot(\hat{s} / \mathrm{L}) / \mathrm{D}, \quad(6)
\end{gathered}
$$

Further, taking into account that $\mathrm{L}=\hat{s} \cdot \mathrm{N}$,

$$
\varepsilon=\left[(\mathrm{n}-1) \cdot\left(\left(\mathrm{S}_{0}+\mathrm{S}_{\mathrm{N}}\right) / 2+\sum \mathrm{S}_{\mathrm{n}^{*}}\right)-\sum \mathrm{S}_{\neq \mathrm{n}^{*}}\right] /(\mathrm{N} \cdot \mathrm{D}),
$$

where, similarly, $\sum \mathrm{S}_{\neq \mathrm{n}^{*}}$ is the sum of the cross-shore profile areas of those profiles which are not multiples of $n$ and obviously $\varepsilon=0$ for $n=1$.

Note that as the nourished density volume or the annual sediment budget increases, the value of $\varepsilon$ decreases. Furthermore, the error is directly proportional to the dimensionless profile spacing, defined as $\hat{s} / \mathrm{L}$, or inversely proportional to N. However, D is fixed for a particular problem and therefore cannot be changed. But, the profile spacing may be altered. The relative error is also proportional to a third factor, in brackets, that represents the heterogeneity of the profiles (HF), which is a function of each particular beach under study.

$$
\mathrm{HF}=\left[(\mathrm{n}-1) \cdot\left(\left(\mathrm{S}_{0}+\mathrm{S}_{\mathrm{N}}\right) / 2+\sum \mathrm{S}_{\mathrm{n}^{*}}\right)-\sum \mathrm{S}_{\neq \mathrm{n}^{*}}\right],
$$

Because this heterogeneity function has the dimensions of a surface, it can be made dimensionless by dividing by the density volume $\mathrm{D}$

\section{Virtual reference bathymetry}

To compute the error described in Equation (6), two bathymetric surveys are needed.

However, how can we determine the optimum spacing, $\hat{s}$, immediately after the first bathymetric survey without waiting until the second is available? In some cases, such as several of those studied herein, it is possible to have previous studies about erosion rates to design a virtual bathymetry without having to perform further studies (and therefore save on costs). Our technique focuses on developing a "virtual" second bathymetric survey to simulate beach conditions after 


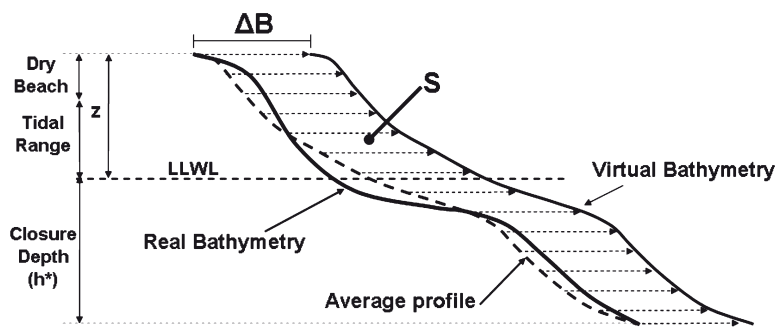

FIG. 4. - Virtual bathymetric survey obtained by displacing the average profile from the initial bathymetry by a constant width $\Delta \mathrm{B}$ calculated as $\mathrm{D} /\left(\mathrm{z}+\mathrm{h}^{*}\right)$, where $\mathrm{D}$ is the volume density (nourishment project) or the erosion/accretion rate (if a previous monitoring is available).

a general change in a beach profile. These changes are based on the one-line theory followed by Hanson (1989), for which it is assumed that the beach profile remains unchanged, allowing beach changes to be described uniquely in terms of the shoreline position.

This virtual topo-bathymetry is obtained by displacing the mean profile from the initial bathymetric survey by a constant width $\Delta \mathrm{B}$ (Fig. 4). This displacement can be seaward (after an accretion) or landward (a set-back, according to Ferreira et al. 2006). To calculate the $\Delta \mathrm{B}$ value, a prior volume density or an erosive rate volume (D) must be assumed on the basis of the annual nourishment sand volume or the annual sediment budget (a previously calculated erosion or accretion rate). A schematic representation of the $\Delta \mathrm{B}$ calculation using the height from the depth of closure to the top berm level is shown in Figure 4.

Thus,

$$
\Delta \mathrm{B} \cdot\left(\mathrm{z}+\mathrm{h}_{*}\right)=\mathrm{D}
$$

where $\mathrm{z}$ is the berm height, i.e. the height between the LLWL and the top of the dry beach level, and $h_{*}$ is the depth of closure, computed following the method of Hallermeier (1981) and Birkermeier (1985).

It is noteworthy that this method is valid not only for nourishment projects carried out in response to an erosive episode but also for customary beach monitoring.

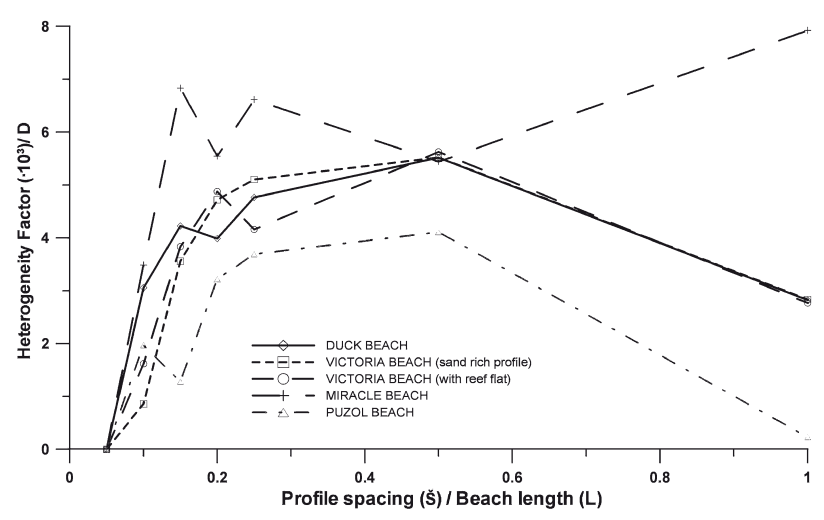

FIG. 5. - Heterogeneity distribution with respect to beach profile spacing/beach length $(\mathrm{s} / \mathrm{L})$ for each beach studied.
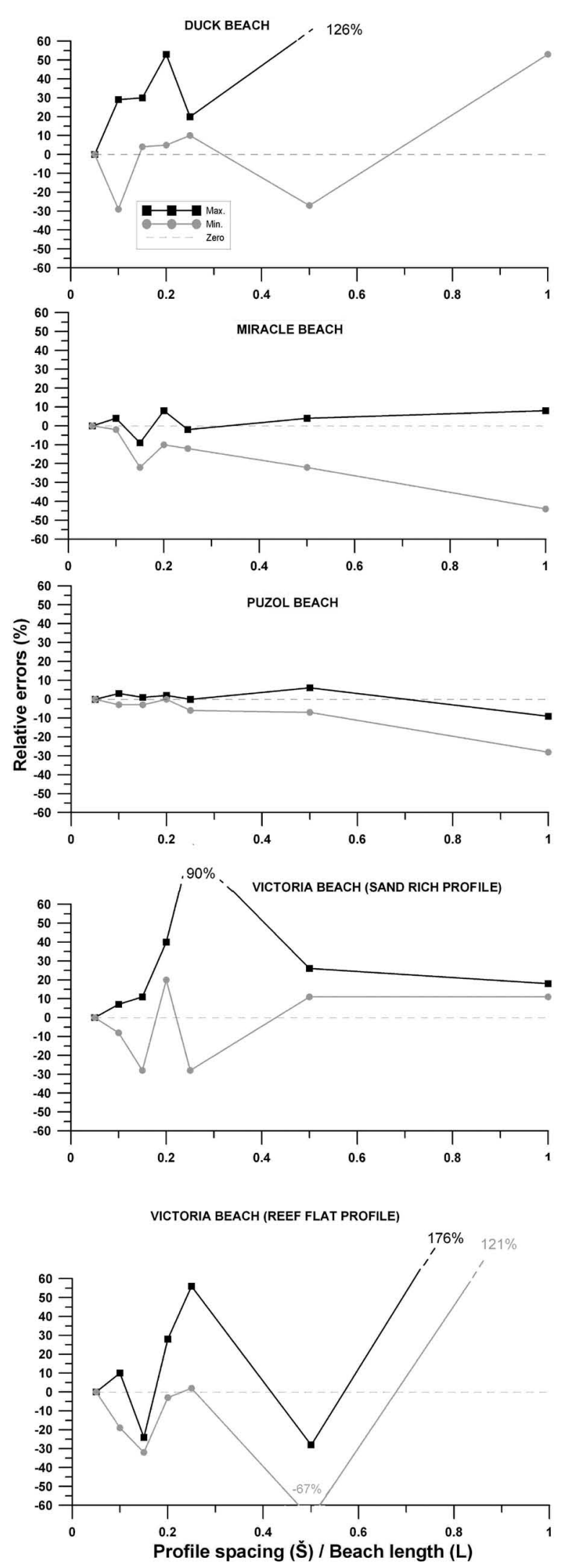

FIG. 6. - Relative error vs. the profile spacing for the different beaches studied. Single profiles correspond to each 1000-m spacing. 


\section{Analysis of beach profile spacings}

Once the two bathymetries have been performed (whether the second bathymetry is real or virtual), the error is computed for each beach and the errors are compared according to their respective dimensionless heterogeneity factors (Fig. 5). However, because of their different lengths (Miracle Beach is $1000 \mathrm{~m}$ long, whereas Puzol Beach is $2000 \mathrm{~m}$ long), a common denominator stretch of $1000 \mathrm{~m}$ was chosen to facilitate the comparison between the beaches analysed. Profile sets were analysed according to the profile spacing selection: 50, 100, 150, 200, 250, 500 and $1000 \mathrm{~m}$ (single profile), corresponding to $\hat{s} / \mathrm{L}$ ratios of $0.1,0.15$, $0.2,0.25,0.5$ and 1 , respectively. To make the most of the data, computations were performed using even or odd profiles for the same $\hat{s}$ whenever possible (Fig. 6). Thus, each odd 100, 150, 200, 250, 500 and $1000 \mathrm{~m}$ and the same even distances were taken into account to compute different volumes. As a result, the volumetric error for each spacing was finally obtained after these volumes had been compared with the overall volume compilation based on the initial bathymetry.

Furthermore, as a parallel study, the beach volume was computed by taking only one profile at a time as a reference. The surface obtained by comparing each single profile with the virtual average profile $\left(\mathrm{m}^{3} / \mathrm{m}\right)$ was multiplied by the total beach length (L) to obtain $\mathrm{N}$ different values for the total volume. Thus, the maximum, minimum and average volumes and their respective relative errors were obtained $\mathrm{N}$ times by taking into account only one distinct profile each time.

\section{RESULTS AND DISCUSSION}

As can be seen in Figure 5, the heterogeneity factor in Atlantic beaches such as Duck Beach and both the sand-rich and reef-flat areas of Victoria Beach show similar values, reaching maximum values when the beach spacing is half the beach length. However, the heterogeneity factor shows a very low value (similar to $\hat{s}=100 \mathrm{~m}$ ) for the $1000 \mathrm{~m}$ spacing. Thus, due to the dependence of the heterogeneity factor with the morphological characteristics of each beach, relative errors do not necessarily increase with larger profile spacing.

It should be pointed out that though it is a Mediterranean beach, Puzol Beach seems to show similar behaviour (but lower error values) to the aforementioned Atlantic beaches. However, the heterogeneity factor may increase greatly in headland-bay beaches, as in the case of Miracle Beach. This may be due to plan-shape variations, which are generated by changes in wave direction.

The computed errors for the different spacings between cross-shore profiles are shown in Figure 6, which depicts the maximum and minimum values (using even and odd profiles). The volume estimated using $50-\mathrm{m}$ spacing between the profiles $(\hat{s} / \mathrm{L}=0.05)$ is used as a reference, in which the error is assumed to be negligible. However, this volume could be computed using a wider spacing when it is not possible to obtain 50 - $\mathrm{m}$ spaced profiles.

It is noted that in all cases values of $\hat{s} / \mathrm{L}=0.1$ lead to average errors of less than 5\%, though they rise to $10 \%$ to $30 \%$ when $\hat{s} / \mathrm{L}$ is increased to 0.25 . Generally, increasing the spacing parameter $\hat{s} / \mathrm{L}$ to 0.5 doubles the error. The error is approximately only $20 \%$ when $\hat{s} / \mathrm{L}=1$ in Miracle Beach, Puzol Beach and the sand-rich area of Victoria Beach, whereas Duck Beach and the reef-protected area of Victoria Beach showed maximum errors of $126 \%$ and $176 \%$, respectively. These results indicate that the existence or absence of a tidal range or a reef does not seem to produce significant changes in the error values (Fig. 6). Thus, in our case, spacings greater than $100 \mathrm{~m}$ lead to significant relative errors in all of the beaches studied, which differ from the admissible spacing limit of 150 to $300 \mathrm{~m}$ considered by other authors such as Wise (1995) or Grosskopf and Kraus (1993). It is important to highlight that because of this heterogeneity it is not always true that the larger the profile spacing is, the larger the error becomes. However, the volumetric error computed using only one profile was enormous for all of the beaches studied and approached $370 \%$.

As a result, we have a method that determines the optimum beach profile spacing from an economic point of view, given an admissible error. For instance, if a 5\% error is admissible in Puzol Beach (see figure 6), a $200 \mathrm{~m}$ profile spacing would be correct but not a $250 \mathrm{~m}$ spacing because the error increases to $10 \%$

\section{CONCLUSIONS}

The methodology presented herein allows the most cost-effective profile spacing to be determined as a function of a specific volume error for any kind of beach. A supplementary goal of this study was to save time and money by using a single accurate bathymetry when the volume density obtained from nourishment projects or erosion/accretion rate (in case of previous monitoring) is available.

Relative errors are obtained by comparing net volumes computed from each specific beach profile spacing with volumes computed from the minimum profile spacing $(50 \mathrm{~m})$.

For all of the beaches analysed, the average error is smaller than $5 \%$ for $\hat{s} / \mathrm{L}=0.1$. Moreover, in our case, when $\hat{s} / \mathrm{L}=0.25$ (i.e. a profile spacing of $250 \mathrm{~m}$ ) errors of $10 \%$ to $30 \%$ appear.

Mathematically, the volumetric error turns out to be proportional to the profile spacing divided by the beach length ratio $(\hat{s} / \mathrm{L})$. However, the relative error is inversely proportional to the volume density (D). Moreover, because of the beach heterogeneity factor, which is site-specific, it is not always true that the error increases with greater profile spacing (e.g. as in Miracle Beach, which has a half-heart shape).

Finally, the methodology appears to be applicable to all kinds of beaches because both the tidal range and 
the presence or absence of reef flats seems to be irrelevant. Among the beaches considered in this study, it can be shown that there are no significant differences in terms of the error. In the cases of Duck Beach and the reef-protected area of Victoria Beach, the error increases significantly as the profile spacing increases.

\section{ACKNOWLEDGEMENTS}

The authors wish to thank Dr. G. Gómez-Pina, Dr. J. Galofré and J. Almenar for providing the survey information (National Coastal Authority, Spanish Ministry of Environmental Protection). The second author thanks the postdoctoral fellowship programme of the Centennial Anniversary Foundation of Kumamoto University for providing financial support.

\section{NOTATION}

The following symbols are used in this paper:

$\mathrm{D}=$ volume density, i.e. the nourished volume per unit length of beach $\left[\mathrm{m}^{3} \cdot \mathrm{m}^{-1}\right]$

$\mathrm{h}_{*}=$ depth of closure $[\mathrm{m}]$

$\mathrm{L}=$ beach length $[\mathrm{m}]$

$\mathrm{n}=$ integer [-]

$\mathrm{n}^{*}=$ multiple of $\mathrm{n}[-]$

$\mathrm{N}+1=$ total number of beach cross-shore profiles [-]

$\mathrm{P}_{\mathrm{i}}=$ cross-shore profiles

$\hat{s}=$ profile spacing $[\mathrm{m}]$

$\mathrm{S}_{\mathrm{N}}=$ cross-shore profile area $\left[\mathrm{m}^{2}\right]$

$\mathrm{V}_{S}=$ sediment volume $\left[\mathrm{m}^{3}\right]$

$\mathrm{Z}=$ berm height $[\mathrm{m}]$

$\Delta \mathrm{B}=$ virtual displacement of the profile $[\mathrm{m}]$

$\varepsilon=$ relative error on sediment volume $[-]$

\section{REFERENCES}

Aarninkhof S., Holman R. 1999. Argus video-based monitoring of the nearshore zone: a tool for both nearshore science and coastal zone management. Backscatter 10(2): 8-11.

Bernstein D.J., Freeman C., Forte M.F., Park J-Y, Gayes P.T., Mitasova H. 2003. Proceedings Coastal Sediments 03, Tampa, Florida, May 2003.

Birkermeier W. 1985. Field data on seaward limit of profile change. J. Waterway, Port, Coast. Ocean Eng. 111(3): 598-602.

Browder A.E., Dean R.G. 2000. Monitoring and comparison to predictive models of the Perdido Key beach nourishment project, Fl., USA. Coast. Eng. 39, 173-191.

Dean R.G. 2002. Beach nourishment: theory and practice. World Scientific Pub. Co. New Jersey, USA. Adv. Ser. Ocean Eng. 18: $399 \mathrm{pp}$.

Ferreira O., Garcia T., Matias A., Taborda R., Dias J.A. 2006. An integrated method for the determination of set-back lines for coastal erosion hazards on sandy shores. Cont. Shelf. Res. 26: 1030-1044.

Garnier R., Ortega-Sanchez M., Losada M.A., Falques A., Dodd N. 2010. Beach cusps and inner surf zone processes: growth or destruction? A case study of Trafalgar Beach (Cádiz, Spain). Sci. Mar. 74(3): 539-553.

Grosskopf W.G., Kraus N. 1993. Guidelines for surveying beach nourishment projects. Technical Note, CETN II-31. U.S. Army Engineering Water Experiment Station, Vicksburg, Mississippi, $12 \mathrm{pp}$.

Hallermeier R.J. 1981. Seaward limit of significant sand transport by waves: An annual zonation for seasonal profiles. Coastal
Engineering Technical Aid CETA 81-2. Fort Belvoir, Coastal Engineering Research Center, U.S. Army Corps of Engineers.

Hanson H. 1989. GENESIS: a generalized shoreline change numerical model. J. Coast. Res. 5(1): 1-27.

Hanson H., Brampton A., Capobianco M., Dette H.H., Hamm L., Laustrup C., Lechuga A., Spanhoff R. 2002. Beach nourishment projects, practices, and objectives - a European overview. Coast. Eng. 47(I.2): 81-111.

Holman R.A., Stanley J. 2007. The history and technical capabilities of Argus. Coast. Eng. 54(6-7): 477-491.

IHO 1998. Standards for Hydrographic Surveys. Special Publication No. 44. Pub. Internacional Hydrographic Organization. Monaco.

Irish J.L., White T.E. 1998. Coastal Engineering applications of high-resolution lidar bathymetry. Coast. Eng. 35: 47-71

Jimenez J.A., Sanchez-Arcilla A. 1993. Medium-term coastal response at the Ebro delta, Spain. Mar. Geol. 114(1-2): 105-118.

Jimenez J.A., Sanchez-Arcilla A., Bou J., Ortiz M.A. 1997. Analysing short-term shoreline changes along the Ebro Delta (Spain) using aerial photographs. J. Coast. Res. 13(4): 1256-1266.

Lippmann T.C., Holman R.A. 1990. The spatial and temporal variability of sand bar morphology. J. Geophys. Res. 95 (C7): 11575-11590.

Menezes J.T., Klein A.H.F. 2006. Morphology and Sedimentary Characterization of a Nourishment Project at Navegantes Beach. J. Coast. Res. SI 39: 869-871.

Micallef A., Williams A.T. 2002. Theoretical strategy considerations for beach management. Ocean Coast. Manage. 45: 261-275.

Moreno L., Tamayo O., Mey J., Martin L., Garcia A., Fernandez M, Fernandez A., Gomez J.A., Diaz J., Tobin D. 2007. Sistema de levantamiento cartográfico y geomorfológico aerotransportado. IX Jornadas Ingeniería de Costas y Puertos. San Sebastián, Spain.

Muñoz-Perez JJ, Tejedor L., Medina R. 1999. Equilibrium beach profile model for reef protected beaches. J. Coast. Res. 15(4): 950-957.

Muñoz-Perez J.J., Lopez B., Gutierrez-Mas J.M., Moreno L., Cuena G.J. 2001a. Cost of Beach Maintenance in the Gulf of Cadiz (SW Spain). Coast. Eng. 42: 43-153.

Muñoz-Perez J.J., Medina R., Tejedor B. 2001b. Evolution of longshore beach contour lines determined by E.O.F. method. Sci. Mar., 65(4): 393-402.

Muñoz-Perez J.J., Medina R. 2010. Comparison of long-, mediumand short-term variations of beach profiles with and without submerged geological control. Coast. Eng. 57: 241-251.

Navarro M., Muñoz-Pérez J.J., Román-Sierra J., Tsoar H., Rodríguez I., Gómez-Pina G. 2011. Assessment of highly active dune mobility in the medium, short and very short term. Geomorphology 129(1-2): 14-28.

NOS 1980. Hydrographic Manual. National Ocean Service, U.S. Government, Printing Office. Washington, D.C.

Plant N.G., Holland K.T., Puleo J.A. 2002. Analysis of the scale of errors in nearshore bathymetric data. Mar. Geol. 191: 71-86.

Rogers S.M. 2000. Beach Nourishment for Hurricane Protection: North Carolina Project Performance in Hurricanes Dennis and Floyd. American Shore and Beach Preservation Association, National Beach Preservation Conf. Aug. 7-10, 2000. 4 pp.

Stauble D.K., Garcia A.W., Kraus N.C., Grosskopf W.G., Bass G.P. 1993. Beach Nourishment Project Response and Design Evaluation: Ocean City, Maryland. Technical Report CERC-93-13. Coastal Engineering Program, U.S. Army Corps of Engineers.

Swales A. 2002. Geostatistical application of short-term changes in beach morphology and sand budget. J. Coast. Res. 18 (2): 338-351.

USACE 2002. Engineering and Design, Hydrographic Surveying. U.S. Army Corps of Engineers, Manual No. 1110-2-1003

Wise R.A. 1995. Recommended base-level physical monitoring of beach fills. CETN II-35. U.S. Army Corps of Engineers. Coast. Eng. Research Center. Vicksburg, Mississippi.

Wright L.D., Short A.D. 1984. Morphodynamic variability of surf zones and beaches: A synthesis. Mar. Geol. 56(1-4): 93-118.

Scient. ed.: J. Guillen.

Received May 11, 2011. Accepted June 20, 2012.

Published online October 15, 2012. 